\title{
The Antibody and Organ Immune Responses of Broiler Starter Fed Diets with Graded Levels of Digestible Lysine
}

\author{
N. G. A. Mulyantini \\ Faculty of Animal Science, University of Nusa Cendana \\ Jln. Adisucipto, Penfui, Kupang, NTT, Indonesia \\ (Received 17-02-2014; Reviewed 14-03-2014; Accepted 28-03-2014)
}

\begin{abstract}
The objective of the study was to investigate broiler immune responses during the starter phase to graded levels of digestible lysine. This experiment used 175 mixed sex broiler chickens from 1 to 21 days of age. Seven chicks were selected and allocated to each floor pens. Chicks were fed experimental diets from one day old to 21 days of age. Dietary treatments included the following levels of digestible lysine: $6.0,8.0,10.0,12.0$ and $14.0 \mathrm{~g} / \mathrm{kg}$ diet. Supplemental synthetic L-Lysine-HCl which was considered to be $100 \%$ digestible was added to diets to obtain the concentration of the digestible amino acid. At 21 days of age, two chickens from each pen with body weights close to the pen mean were selected for evaluation of immunological variables. Immune organs (spleen and bursa), cellular immune response (skin test), and antibody production against infectious bronchitis virus (IBV) were determined. Blood samples (plasma) were taken from the same birds to determine antibody titer against IBV. The birds were euthanized, and immune organs (spleen and bursa) were removed, and weighed individually. The results showed that spleen and bursa weight of birds fed diet containing $6.0 \mathrm{~g} / \mathrm{kg}$ digestible lysine was significantly lower than those given diet containing 10 to $14 \mathrm{~g} / \mathrm{kg}$ of digestible lysine. Toe web thickness of chickens fed diet containing $6.0 \mathrm{~g} / \mathrm{kg}$ digestible lysine was significantly lower than the birds fed diets containing $14 \mathrm{~g} / \mathrm{kg}$ digestible lysine. In conclusion, diet containing $8.0 \mathrm{~g} / \mathrm{kg}$ appeared to have greatest potential to modulate immune response among other levels. However increasing levels of lysine did not have significant effect on antibody production.
\end{abstract}

Key words: amino acid, lysine, broiler, digestible

\section{ABSTRAK}

Penelitian ini menggunakan 175 broiler jantan dan betina dari umur satu hari sampai 21 hari. Tujuh ayam ditempatkan pada petak kandang dan diberi ransum penelitian dari umur 1 sampai 21 hari. Ransum penelitian adalah ransum dengan perbedaan level asam amino lisin yang tercerna, yaitu 6,$0 ; 8,0 ; 10,0 ; 12,0 ;$ dan 14,0 g/kg ransum. L-Lisin-HCL sintetis yang diasumsikan $100 \%$ tercerna ditambahkan pada ransum untuk memperoleh konsentrasi asam amino tercerna. Pada umur 21 hari, 2 ekor ayam dari masing-masing petak dipilih untuk mengevaluasi variabel kekebalan tubuh. Variabel tersebut adalah bobot organ imun (spleen dan bursa), respons dari sel imun (test kulit) dan produksi antibodi melawan virus infeksi bronkitis (IBV). Sampel plasma darah diambil dari ayam yang sama untuk menentukan titer antibodi melawan virus infeksi bronkitis. Hasil penelitian menunjukkan bahwa bobot organ imun (spleen dan bursa) pada ayam yang diberi ransum dengan level lisin tercerna sebesar 6,0 $\mathrm{g} / \mathrm{kg}$ nyata lebih rendah dibandingkan dengan bobot organ imun pada ayam yang diberi ransum yang mengandung lisin tercerna 10-14 $\mathrm{g} / \mathrm{kg}$. Ketebalan toe web ayam yang diberi ransum $6,0 \mathrm{~g} / \mathrm{kg}$ lisin tercerna nyata lebih rendah dibandingkan dengan ketebalan toe web dari ayam yang diberi ransum yang mengandung $14 \mathrm{~g} / \mathrm{kg}$ lisin tercerna. Kesimpulan, ransum dengan level lisin tercerna $8,0 \mathrm{~g} / \mathrm{kg}$ tampak memberikan respons yang paling baik terhadap respons imun dibandingkan dengan level yang lainnya. Namun demikian, tidak ada perbedaan yang nyata dalam produksi antibodi diantara broiler yang diberi ransum dengan perbedaan level lisin tercerna.

Kata kunci: asam amino, lisin, broiler, tercerna

*Corresponding author:

E-mail: ngamulyantini@yahoo.com.au 


\section{INTRODUCTION}

With the future loss of antibiotics from poultry diets, there will be an increased reliance on the bird's immune system to mitigate against disease challenges during growth. For this reason, it was decided to undertake initial investigations on the relationship between digestible amino acid requirements and immune function in growing chickens. Lysine is considered to be the second most limiting amino acid in broilers diets (Lemme et al., 2004). As all amino acids are in relation to lysine in an ideal ratio, it is important to have an accurate lysine digestible requirement for chickens to optimize growth and production. If errors are made in the determination of the lysine requirement, all other amino acids will also be estimated incorrectly. Digestible amino acids values are more beneficial than requirements expressed on a total basis (Bryden \& Li, 2010). Lysine is used as the reference amino acids for the ideal amino acids profile because more information is known about its concentration in feedstuffs (Campbell, 2004). Extensive work has been done to estimate amino acids requirement of poultry (Sklan \& Noy, 2003; Indarsih, 2009; Star et al., 2012). The requirements vary greatly depending on the response criteria and the mathematical model applied for estimation. Increasing dietary levels of lysine improved growth performance, increased breast meat yield and reduced abdominal fat content (Dozier et al., 2010; Dozier \& Payne, 2012; Mahdavi et al., 2012; Mejia et al., 2012). Lysine has also been shown to benefit immune function when added to poultry diets at higher concentrations than are required to maximize growth and feed efficiency (Chen, et al., 2003). However, deficiency or excess of dietary amino acids will also alter immune response.

All the above studies were based on total amino acid values where graded levels of synthetic amino acids were added. To date no studies have been conducted on ileal digestible lysine requirement for immune response of broiler starter. Therefore, accurate estimates of ileal digestible lysine requirements need to be obtained for immune response and immune organ, such as bursa (source of B- lymphocytes that produce antibody) and thymus (source of T-lymphocytes that regulate immune function and kill virus-infected cells) of broiler chickens. This experiment was conducted to investigate broiler chicken immune responses during the starter phase to graded levels of digestible lysine.

\section{MATERIALS AND METHODS}

\section{Chicken and Experimental Diets}

Chicken. This experiment used 175 mixed sex broiler chicken from 1 to 21 days of age. Chicks (strain ISA and Lohman 202) were obtained from a local hatchery, wing tagged and weighed individually. Birds were allocated so that the average initial body weights for each floor pen were similar $(45 \pm 2.9 \mathrm{~g})$. Seven chicks were selected and allocated to each floor pens, so there were 25 pens used in this study.
Diets. Chicks were fed experimental diets from one day old to 21 days of age. Analysis of the diets on as fed basis is shown in Table 1. Dietary treatments included 5 titrated levels each of digestible lysine added to the basal diet (NRC, 1994). Dietary treatments included the following levels of digestible lysine: 6.0, 8.0, 10.0, 12.0 and $14.0 \mathrm{~g} / \mathrm{kg}$ diet. The levels of other amino acids were similar among treatments and set as recommended by the University of Illinois for digestible amino acid requirements of broilers. Supplemental synthetic L-Lysine- $\mathrm{HCl}$ digestible was added to diets to obtain the concentration of the digestible amino acid (AOAC, 2006).

\section{Immunological Assessment}

At 21 days of age, two chickens from each pen with body weights close to the pen mean were selected for evaluation of immunological variables. Immune organ (spleen and bursa), cellular immune response (skin test), and antibody production against infectious bronchitis virus (IBV) were determined. After skin thickness measurement, blood samples (plasma) were taken by cardiac puncture from the same birds to determine antibody titer against IBV. The birds were euthanized by injection

Table 1. Nutrient composition of starter basal diet on an as fed basis (1-21 days of age)

\begin{tabular}{lr}
\hline \multicolumn{1}{c}{ Analysis $(\mathrm{g} / \mathrm{kg})$} & Lysine basal diet \\
\hline Protein & 214.00 \\
Fat & 32.11 \\
Calcium & 10.02 \\
Phosphorus & 4.51 \\
AME $(\mathrm{MJ} / \mathrm{kg})$ & 12.47 \\
Lysine & 7.51 \\
Methionine & 4.68 \\
Methionine + cystine & 7.65 \\
Threonine & 10.18 \\
Tryptophan & 2.25 \\
Arginine & 14.33 \\
Valine & 11.68 \\
Leucine & 20.50 \\
Isoleucine & 9.70 \\
Choline (ppm) & 1523 \\
Digestible lysine & 6.00 \\
Digestible methionine & 4.25 \\
Digestible threonine & 7.88 \\
Digestible tryptophan & 1.90 \\
Digestible arginine & 12.39 \\
Digestible valine & 8.99 \\
Digestible leucine & 16.52 \\
Digestible isoleucine & 7.89 \\
Digestible valin & 8.99 \\
Digestible histidine & 4.10 \\
Digestible phenylalanine & 8.56 \\
\hline & \\
&
\end{tabular}


with sodium pentabarbitone and immune organs (spleen and bursa) were removed and weighed.

Cellular immune response. Cellular immune response was quantified in vivo using established procedures (Klalifeh, 2009) by injecting phytohaemagglutinin (PHAP) (L-9132 Sigma, Australia) $100 \mu \mathrm{g}$ in $0.1 \mathrm{~mL}$ saline solution, into the right foot web and $0.1 \mathrm{ml}$ saline solution into the left foot web as a control treatment. The measurement of the inter digital skin swelling was made to the nearest $0.01 \mathrm{~mm}$ before and $24 \mathrm{~h}$ following the injections. Toe web swelling in response to PHA-P in the cutaneous basophile hyper sensitivity test was measured with a constant tension micrometer. The degree of swelling was deemed to indicate the level of cellular immune respons. The results are presented as increase in toe web thickness measured in millimeters. A skin thickness change (ST) was calculated as the difference between the thicknesses of inters digital skin before (T0) and $24 \mathrm{~h}$ (T24) after injections. Stimulation of skin thickness (SST) was determined as the difference between PHA-injected thickness (STPHA) and saline injected thickness (ST saline), using the following formulas:

STsaline $=$ STsalineT2 $4-$ STsalineT0

STPHA = STT24 - STT0

SST = STPHA - STsaline

Immune organs. The proportional weight of each organ, as a measure of immune response was calculated as follows:

Bursa of fabricius $(\%)=$ Bursa of fabricius weight $(\mathrm{g}) \mathrm{x}$ 100 g Body weight

Spleen $(\%)=$ Spleen weight $(\mathrm{g})$ x $100 \mathrm{~g}$ Body weight

Antibody evaluation. Humoral immunity was evaluated by measuring the primary antibody response against IBV. An ELISA (Enzyme-Linked Immunosorbent Assay) test kit (IDEEX, Australia) was used to evaluate antibody responses to IBV vaccine from a plasma sample. Plasma was collected by centrifugation at $500 \mathrm{G}$ for $10 \mathrm{~min}$ and heat inactivated for $30 \mathrm{~min}$. The plasma samples were stored at $-20^{\circ} \mathrm{C}$ until analysed. The antibody titers were expressed as the $\log 2$ of the highest dilution of plasma that agglutinated an equal volume of $0.5 \%$ IBV. Antibody titre $(\log 10$ titre $)=1.09(\log 10 \mathrm{~S} / \mathrm{P})+3.3 .6$, where: $\mathrm{S} / \mathrm{P}$ is the relative level of antibody calculated as the sample to positive $(\mathrm{S} / \mathrm{P})$ ratio as recommended in the kit.

\section{Statistical Analysis}

A completely randomized design was used in this research. Data for immune responses were subjected to ANOVA procedures appropriate or completely randomized design (Steel \& Torie, 1980) by using the General Linear Model (GLM) procedure of SAS software. Superscripts were used in tables to indicate statistical differences between means. The significant level was set at $\mathrm{P}<0.05$ and, if the F-ratio indicated significance, the differences between the means were separated using the Least Significant Difference test (Steel \& Torrie, 1980).

\section{RESULTS AND DISCUSSION}

The results of immune organ development and immune response are shown in Table 2. Overall, the lymphoid organ and cellular immune function (toe web thickness) were significantly $(\mathrm{P}<0.05)$ affected by the dietary levels of lysine. However, increasing levels of lysine did not have significant effect on antibody production. Spleen and bursa weight of birds fed diet containing $6.0 \mathrm{~g} / \mathrm{kg}$ digestible lysine was significantly lower than those of birds given diet containing 10 to 14 $\mathrm{g} / \mathrm{kg}$ of digestible lysine. The relative spleen weight was similar among treatments. The relative bursa weight varied inconsistently among treatments. Toe web thickness of chickens fed diet containing $6.0 \mathrm{~g} / \mathrm{kg}$ digestible lysine was significantly lower than birds fed diets containing $14 \mathrm{~g} / \mathrm{kg}$ digestible lysine. Antibody production against infectious bronchitis virus (IBV) did not affected by the dietary levels of lysine.

The smaller size of all immune organs was likely related to the body weight reduction. This is similar to other studies (D'Mello, 2003b) where lysine deficiency severely reduced the body and organ weights. However, Dozier \& Payne (2007) found that the bursa responds well to lysine deficiency by increasing its ability to take up lysine from the blood (relative to the abilities of other tissues, such as muscle) and maintains normal cell numbers. Animals preserve the antibody-preserving arm of the immune system during malnutrition while the regulatory, T-lymphocyte arm of the immune response is diminished (Klasing, 2007).

Chen et al. (2003) found that enlargement of the spleen is associated with immune stimulation. However, this finding was surprising since enlargement of the

Table 2. Immune parameters of broiler chickens fed diet with different lysine levels

\begin{tabular}{|c|c|c|c|c|c|c|}
\hline \multirow{2}{*}{ Parameters } & \multicolumn{5}{|c|}{ Digestible lysine levels (g/kg) } & \multirow{2}{*}{$\mathrm{P}$ - value } \\
\hline & 6 & 8 & 10 & 12 & 14 & \\
\hline Spleen weight (g) & $0.34 \pm 0.23^{c}$ & $0.66 \pm 0.20^{\mathrm{ab}}$ & $0.65 \pm 0.18^{\mathrm{ab}}$ & $0.64 \pm 0.15^{\mathrm{ab}}$ & $0.68 \pm 0.15^{\mathrm{a}}$ & 0.002 \\
\hline Spleen/BW (\%) & $0.08 \pm 0.04$ & $0.09 \pm 0.03$ & $0.08 \pm 0.02$ & $0.07 \pm 0.02$ & $0.08 \pm 0.02$ & 0.667 \\
\hline Bursa weight (g) & $0.81 \pm 0.30^{\mathrm{d}}$ & $1.20 \pm 0.19^{c}$ & $1.37 \pm 0.32^{\mathrm{bc}}$ & $1.51 \pm 0.24^{b}$ & $1.86 \pm 0.36^{\mathrm{a}}$ & 0.000 \\
\hline Bursa/BW (\%) & $0.19 \pm 0.05^{\mathrm{ab}}$ & $0.22 \pm 0.04^{\mathrm{a}}$ & $0.18 \pm 0.04^{\mathrm{b}}$ & $0.19 \pm 0.03^{b}$ & $0.23 \pm 0.04^{\mathrm{a}}$ & 0.044 \\
\hline Toe web (mm) & $0.01 \pm 0.12^{\mathrm{b}}$ & $0.06 \pm 0.10^{\mathrm{ab}}$ & $0.10 \pm 0.12^{\mathrm{ab}}$ & $0.06 \pm 0.12^{\mathrm{ab}}$ & $0.13 \pm 0.12^{\mathrm{a}}$ & 0.130 \\
\hline Antibody (log 10 titre) & $2.56 \pm 0.24$ & $2.84 \pm 0.30$ & $2.73 \pm 0.41$ & $2.63 \pm 0.35$ & $2.49 \pm 0.40$ & 0.206 \\
\hline
\end{tabular}

Note: Means in the same row with different superscript differ significantly $(\mathrm{P}<0.05)$. 
spleen was not affected by antibody production. The birds fed diets containing $8.0 \mathrm{~g} / \mathrm{kg}$ of digestible lysine had the highest antibody production against IBV. This suggested that the level of $8.0 \mathrm{~g} / \mathrm{kg}$ might be influence antibody production but it was not different statistically from the other treatments.

In the present study suggested that there was a negative relationship between growth and immunity. Birds with high body weight allocate more nutrients towards muscle growth and less towards defense mechanism. Zhang et al. (2006) found that body weight of broiler starter significantly increased $(\mathrm{P}<0.001)$ with increasing level of digestible lysine from $6.0 \mathrm{~g} / \mathrm{kg}$ to $14 \mathrm{~g} / \mathrm{kg}$. Body weight of broilers starter fed diet containing $6.0 \mathrm{~g} / \mathrm{kg}$ digestible lysine was $378 \mathrm{~g}$, and body weight of broilers starter fed diet containing 8.0,10, $12 \mathrm{~g} / \mathrm{kg}$ and digestible lysine was 520, 721, and $812 \mathrm{~g}$, respectively. In this study shown that increasing level of digestible lysine tended to decrease antibody production, eventhough statistically was not different between treatment.

Published values for digestible lysine requirements for broilers vary widely (Dozier et al., 2010; Mahdavi et al., 2012; Mejia, 2012). Different results from the previous studies may be due to differences in strain of birds and diets. The variation of strain may be contributed to different expression of the genes associated with lysine utilization. In terms of diet, it might be different crude protein content between recent study and previous studies. At the higher crude protein concentrations imply substantial decreases in the efficiency of lysine utilization (D'Mello, 2003b).

Klasing (2007) estimated that rates of amino acids incorporation into leukocytes, and accessory proteins indicate that the resting immune system utilizes only about $1.2 \%$ of the lysine intake in a healthy growing broiler chick. However, during a robust immune response, production of protective accessory proteins was increased by the liver. These anabolic processes increase nutrient use by the immune system by almost 6 -fold in the case of lysine (from $1.2 \%$ to $6.7 \%$ of lysine intake). For nutrients for which the immune system is most vulnerable due to a low priority for acquisition, requirements set based on maximal weight gain or FCR are likely to be inadequate for optimal disease resistance. Low immune response is possibly due to reduced protein availability for liver protein synthesis associated with immune response or antibody production (Murwani, 2008).

\section{CONCLUSION}

Diet containing $8.0 \mathrm{~g} / \mathrm{kg}$ appears to have greatest potential to modulate immune response among other levels. However increasing levels of lysine does not have significant effect on antibody production.

\section{REFERENCES}

AOAC. 2006. Official Methods of Analysis. 18th ed. Association of Official Analytical Chemists, Arlington, VA.

Bryden, W. L. \& X. Li. 2010. Amino acid digestibility and poultry feed formulation: expression, limitations and application. Revista Brasileir de Zootenica 39:279-287. http://dx.doi.
org/10.1590/S1516-35982010001300031

Campbell, L. 2004. IDEA- A way to determine the amino acid digestibility of poultry feedstuffs. Farmers Independent Weekly. Faculty of Agricultural and Food Science, University of Minnetoba, Canada. pp. 1-2.

Chen, C., J. E. Sander, \& N. M. Dale. 2003. The effect of dietary lysine deficiency on the immune response to Newcastle disease vaccination in chickens. Avian Dis. 47: 1346-1351. http://dx.doi.org/10.1637/7008

Dozier, W. A. III \& R. L. Payne. 2012. Digestible lysine requirements of female broilers from 1 to 15 days of age. J. Appl. Poultry Res. 21: 348 -357. http://dx.doi.org/10.3382/ japr.2011-00418

Dozier, W.A., III, A. Corzo, M. T. Kidd, P. B. Tillman, J. P. McMurtry, \& S. L. Branton. 2010. Digestible lysine requirements of male broilers from 28 to 42 days of age. Poultry Sci. 80: 2173-2183. http://dx.doi.org/10.3382/ps.2010-00710

D'Mello, J. P. F. 2003. Responses of growing poultry to amino acids. In: J. P. F. D'Mello (Ed). Amino Acids in Animal Nutrition. CAB International, Wallingford, UK. pp. 237-265. http://dx.doi.org/10.1079/9780851996547.0237

Indarsih, B. 2009. Response of two different strains of commercial broilers to different dietary amino acid allowance. Med. Pet. 32:104-111.

Khalifeh, M. S., M. M. Amawi, E. A. Abu-Basha, \& I. B. Yonis. 2009. Assessment of humoral and cellular-mediated immune response in chickens treated with tilmicosin, florfenicol, or enrofloxacin at the time of Newcastle disease vaccination. Poultry Sci. 88:2118-24.

Klasing, K. C. 2007. Nutrition and the immune system. Brit. Poultry Sci. 48: 525-537. http://dx.doi.org/10.1080/0007166 0701671336

Lemme, A., V. Ravindran, \& W. L. Bryden. 2004. Standardized ileal amino acid digestibility of raw materials in broilers. Proc. Multi-State Poultry Feeding and Nutrition and Health and Management Conf. and Degussa Corp's Technical Symp., Indianapolis, IN.

Mahdavi, A., M. Shivazad, F. Alemi, M. Zaghari, H. Moravej, \& B. Darabighane. 2012. Digestible lysine requirement of broilers based on practical diet. Ital. J. Anim. Sci. 11:68-76. http://dx.doi.org/10.4081/ijas.2012.e13

Mejia, L., C. D. McDaniel, \& A. Corzo. 2012. Dietary influence of digestible lysine concentration on Cobb 500 hen broiler breeder reproductive performance. Poultry Sci. J. 91: 426431. http://dx.doi.org/10.3382/ps.2011-01710

Murwani, R. 2008. Effect of corn or sorghum in combination with soybean meal as feed ingtredients on the serum antibody titres to NDV vaccine in broiler chickens. International Journal of Poultry Science 7: 497-501. http://dx.doi. org/10.3923/ijps.2008.497.501

NRC. 1994. Nutrient Requirements of Poultry. 9th rev. ed. National Academy Press, Washington, DC.

SAS Institute Inc. and World Programming Limited. 2010. England and Wales High Court (Chancery Division).

Sklan, D. \& Y. Noy. 2003. Crude protein and essential amino acid requirements in chicks during the first week posthatch. Brit. Poultry Sci. J. 44:266-274. http://dx.doi.org/10 $.1080 / 0007166031000124586$

Star, L., M. Rovers., E. Corrent, \& J. D. van der Klis. 2012. Threonine requirement of broiler chickens during subclinical intestinal Clostridium infection. Poultry Sci. J. 91: 643-652. http://dx.doi.org/10.3382/ps.2011-01923

Steel, R. G. D. \& J. H. Torrie. 1980. Principles and Procedures of Statistics. A Biometrical approach. 2nd ed. McGraw Hill Book Co., Inc., New York.

Zhang, D., X. Li., H. K. Huang, H. T. Hoai, N. G. A. Mulyantini, A. Kumar, \& W. L. Bryden. 2006. The response of broilers to dietary digestible lysine levels in the starter phase. Proceedings of the Australian Poultry Science Symposium. Vol. 18, p. 48. 